\title{
Study on the Personnel Training Mode of the Innovative Education in Logistics
}

\author{
Si-Qi ZHANG* \\ Traffic Engineering School \\ Shenyang Jianzhu University \\ Shen Yang, China \\ zhangsiqicn@126.com
}

\author{
Xiao-Yu WU \\ Traffic Engineering School \\ Shenyang Jianzhu University \\ Shen Yang, China \\ $1172029446 @ q q . c o m$
}

\author{
Yun-Feng ZHANG \\ Traffic Engineering School \\ Shenyang Jianzhu University \\ Shen Yang, China \\ $1076347676 @ q q . c o m$
}

\begin{abstract}
The lack of innovative talents in logistics is a bottleneck that restricts the development of the country and society. The cultivation of creative talents is not only the urgent need of the present era, but also the inevitable choice of all colleges and universities. In order to further cultivate the innovative ability of college students, this paper reforms the original teaching system and puts forward some important measures to improve the quality of personnel training. Through the establishment of a sound curriculum evaluation system and quality assurance system, the article discusses in detail the ways to reform the personnel training mode in colleges and universities and enhance the training of personnel. In the end, the article puts forward the innovation path of innovation-oriented high-end skilled personnel training mode.
\end{abstract}

Keywords-personnel training mode; innovative education; the countermeasures proposed; teaching innovation

\section{INTRODUCTION}

Under the guidance of educational theories and educational thoughts, the mode of personnel training refers to the construction of knowledge and ability structure for educator and the realization of such structure with systematic teaching content and perfect management system according to certain training objectives and personnel specifications Strategy system. Overall, the model of personnel training should focus on "what kind of person to be trained" and "how to train people". At the same time, this is also a summary of the entire personnel training process. Personnel training mode is the core of personnel training, but also the most fundamental content [12].

The National Medium and Long-Term Education Reform and Development Plan (2010-2020) stipulates: To meet the needs of national and social development, follow the laws of education and the law of talent growth, deepen the reform of education and teaching, innovate the teaching methods of

This work is partially supported by 2017 logistics reform project (No. JZW2017109). education, explore ways of training. The formation of various types of talents, top-notch innovative talents in logistics continue to emerge. Thus it can be seen that the construction and implementation of innovative personnel training mode is the core task of the Chinese higher education sector for some time to come[4,5]. The Plan for Implementing Innovative talents in logistics also raised the demand for training innovative talents in logistics in higher education institutions in 2011. All colleges and universities should create an environment for cultivating innovative talents in logistics according to their own actual conditions, and then break through the difficulties in the mechanism of personnel training and form distinctive innovative personnel training modes. This also provides an effective basis for the promotion of innovative talents in logistics in higher learning institutions [6].

\section{THE INNOVATIVE EDUCATION IN LOGISTICS THOUGHTS AND CONSCIOUSNESS}

Innovative education in logistics and innovative personnel training ideas must be converted into a self-consciousness of the development of innovative education in logistics and innovative personnel training, will become source of thought and real power of education innovation and development in knowledge-based economy era. Educational ideas, concepts and consciousness, in the final analysis, are the ideologies to establish what kind of teaching conception, teachers and students conception, talented conception and quality conception. Whether we insist "examination-oriented education" values or the quality of education in values; whether we insist "closed" concept of education, or the "open" concept of education; whether we insist the "transmission type" education concept in the agricultural civilization time and the "standard type" teaching concept in the industrial civilization time, or innovative teaching concept in the era of knowledgeeconomy ; whether we insist "dignity of the teaching profession" concept or the concept of teacher-student equality 
and democracy. Whether the students who are good at "endorse" to "examination" are good students, or the students who do well in studying and students, and so on. Not only have been completely solved these problems in theory but also in practice, they still required research and exploration diligently.

Objectively speaking, at the current university education system and teaching method in our country, the conservative, lagging and obsolete education consciousness and ideological concept of pedagogue is the greatest obstacle to carry out innovative education in logistics and innovative personnel training. The creative education idea reflects the nation and society's basic cognition and requirement to education, so educational thought and concept of the pedagogues must adapt with it. However, it is not easy to renew educational concept because traditional educational thinking is ingrained and far reaching. In addition, the time of carrying out quality and innovation education allover is not long in our nation, people's cognition, especially the teaching first-line managers and teachers, still stay in perceptual stage, so we must pay attention to building creative education idea which should be geared to the development of knowledge economy ear. Otherwise, education consciousness and ideological concept cannot change completely, everything will lost dynamic and turn to empty words $[7,8]$.

\section{THE COUNTERMEASURES OF INNOVATIVE PERSONNEL} TRAINING

Universities should take cultivation of innovative talents in logistics as important measures for the development planning of universities. It need to build an innovative personnel training system, and build a student work management team that adapts to the cultivation of creative talents for college students. Universities should continue to strengthen theoretical research and practical exploration of innovative personnel training. And universities need to actively promote innovative cooperation between school and enterprise to obtain a new model of innovation and education.

\section{A. Teaching innovation Based on Innovative education in logistics}

With the construction of the national innovation system and the development of higher education, the reform of the original teaching system and the further cultivation of the innovative ability of professional undergraduates have become major measures to improve the quality of personnel training. Universities conform to the trend of the times, a clear idea of the overall reform of education: Taking "improving teaching quality and innovative teaching methods" as the general guiding principle, "taking students as the center" as the basic principle and "learning by output as the basis" to evaluate the teaching effect and improving the practice and innovation ability of undergraduates actively promote undergraduate research teaching. Specific countermeasures are as follows:

- Deepen the curriculum and teaching reform, innovative teaching methods. First of all, it reforms the teaching content, strengthen the foundation, broaden the professional caliber and embody the principle of "thick foundation and wide caliber"; Second, through the reform of curriculum system, the transformation of "identity" course to "creative" course is realized. This way will be students' learning from the perception and memory levels up to the height of imagination and thinking.

- Further strengthen the practical teaching rationalization arrangements, increase students practice hands-on opportunities. On the basis of existing practice teaching, universities should further optimize the teaching arrangements, so that students can be more integrated into the practice of classroom teaching. Universities should arrange as many independent practice teaching as possible and innovate the combination of research training and graduation thesis.

- Improve teachers' incentive mechanism. Universities should actively guide and encourage teachers to absorb and apply innovative teaching concepts and methods, and actively engaged in teaching research reform issues. Teacher job evaluation and job title assessment work should highlight the undergraduate teaching research evaluation. During the review process, efforts should be made to improve the proportion of teaching performance so as to improve the teachers' enthusiasm for carrying out the education reform study. Universities should increase the introduction of outstanding talents. In order to improve the overall teaching and research level of teachers, teachers should change the single source of teachers' employment status in the appointment system of teachers, adopt the mode of open and competitive appointment, and choose the best ones.

- Increase the funding for teaching reform and innovation support and support efforts. Each year in the budget, universities should invest the necessary funds and thematic support for teaching reform projects. Also, colleges support scholarship research papers by rewarding each article.

- Positive guidance of teachers on teaching reform and development trend of education reform project research. Universities require each major to declare one educational reform project at least one year. The research on educational reform projects should be in line with the overall development direction and planning of universities. It should focus on improving teaching quality and innovative teaching methods to be carried out. Educational reform projects give greater guidance for the project which improve teaching quality and innovative teaching methods.

\section{B. Construction of innovation and entrepreneurship platform}

The college students' innovation and entrepreneurship training program carries out two levels of management at the university level and at the college level. Universities set up the leading group of undergraduate innovation and entrepreneurship training program. Leading group leader is in charge of teaching vice president. Leading group members are consisted of the Academic Affairs Office, Science and Technology Department, Assets Department, Planning and Finance Department, Personnel Office, Students Department, 
Youth League and Enrollment and Employment Department and other relevant departments responsible. The leading group is responsible for overall leadership, planning, organizing and coordinating the implementation of the innovation and entrepreneurship training programs for university students, adjusting and formulating relevant policies and systems so as to ensure that all the planned work can be implemented. It sets up the Office of Innovation and Entrepreneurship under leading group. The office is located in the Development Center of College Students Innovation and Entrepreneurship. Office is responsible for the implementation of daily work. Each college set up a college student innovation and entrepreneurship training program working group. The team leader is headed by the school president. The working group appoints relevant vice presidents and teachers. The working group is responsible for the overall planning of innovation and entrepreneurship in universities as well as the organization and implementation of the training plan for university students' innovation and entrepreneurship, and recommends the selection of candidates for school-level candidates to universities.

\section{Construction and protection measures of science technology and innovation and entrepreneurship system}

Universities should attach importance to and encourage students to engage in extracurricular activities in innovation and entrepreneurship and participate in all kinds of academic, science and technology, entrepreneurship and other competitions, such as, college student's innovation and entrepreneurship training program. For the achievements of the competition universities should be given recognition and reward. When the scholarship selection or promotion of graduate students, universities should give some policies.

\section{Strengthen training of innovation ability of graduate students}

Universities should encourage graduate students to engage in cutting-edge, practical application of significant scientific research topics. It strengthens graduate instructors to engage in scientific research activities. By relying on the platform of key laboratories, universities encourage graduate students to participate in many projects such as the National Natural Science Foundation of China, the Ministry of Construction Science Research Project, the Liaoning Provincial Nature Fund Project, the Liaoning Provincial Department of Education Project and the Liaoning Provincial Communications Department Research Project. This way greatly cultivates the scientific research ability of graduate students. At the same time, it is necessary to strengthen the synergistic innovation mechanism of production, learning and research so as to enhance the combination of theory and practice among postgraduates and the capability of scientific and technological innovation by relying on joint training bases for postgraduates. Through local service projects, the research results will be applied in practice to develop the ability to combine the theory and practice of postgraduates.

\section{E. The Innovative Teaching Process for Higher Education}

In the era of innovative education in logistics and innovative personnel training research and practice are going on the way which their predecessors did not finish overnight effectively. And it must be required a relatively longer period of time of exploration and practice. Higher Education calls for innovation, but as most colleges and institutes which cultivate innovative talents in logistics mention the Educational Innovation, they tend to form a pattern in order to focus on various forms of scientific research organizations, groups or task groups, encourage students to participate in scientific research, engage in small inventions, small creations, small innovations, small design, small production, or in extracurricular activities to carry out creative thinking training, as a result that a kind of substantial increase in the workload of teaching, students study the normal occupied substantial time. Therefore, teachers and students are overwhelmed, exhausted. How to seize the full points to promote innovative education in logistics and cultivate innovative talents in logistics in the regular teaching activities, especially the innovative education in logistics idea that through the teaching process, combined with teaching for all students in a lively and diverse forms of creative education. This issue has existed for a hundred years, "Creative Education" has not yet been well solved, but also the era of knowledge economy and innovation in today's education is facing new problems.

Innovational education is basic value orientation of education that cultivate persons to have innovative spirit and innovative capability, innovative spirit and ability undoubtedly can cultivate innovative education in logistics to step into the classroom teaching process innovation as main form of teaching and learning activities - classroom teaching, must always embody pursuit of such values. Extra-curricular activities carried out innovative skills training is very important, but if it drifts out from the classroom teaching, and neglect innovative spirit and innovation capacity-building in innovative teaching and learning process, it will not be vitality, it will have difficulty to put specific innovative capabilities into individual psychological quality. As we can see, lots of failure innovative teaching approaches of colleges and universities or unsuccessful have proven this point.

\section{CONCLUSION}

The cultivation of creative talents is not only the urgent need of the present era, but also the inevitable choice of all universities. University is a base for training innovative talents in logistics. The potential of innovative talent is explored in universities. The knowledge base of innovative talents in logistics can be accumulated in universities. Creative thinking ability of innovative talents in logistics can be cultivated in university. Creative personality characteristic of innovative talents in logistics are shaping at universities. The comprehensive innovation ability of innovative talents in logistics has been nurtured in universities.

The cultivation of innovative talents in logistics in universities should be based on the development of practical training objectives. Universities should adopt innovative teaching methods and means of education to strengthen the "double division" team. It is necessary to establish all-round, deep, close cooperation between school and enterprise. Through the establishment of course evaluation system and quality assurance system, this paper discusses in detail the 
measures to reform the personnel training mode and improve the personnel training level in universities. And the article puts forward the innovative way of innovation oriented high-end skilled personnel training mode. In the process of personnel training in universities, the key that "combination of work and study" can really be implemented is to achieve a "win-win situation between schools and enterprises". Local government should give full play to the government functions so as to introduce of appropriate policies to support enterprises to accept intern. At the same time, local governments should encourage their technical backbone to engage in practical teaching in schools for a long time.

\section{ACKNOWLEDGMENT}

This work is partially supported by 2017 logistics reform project (No. JZW2017109).

\section{REFERENCES}

[1] Xiong Ying, "Development of Economic Knowledge and Reform of Higher Education,” Journal of University of Electronic Science and Technology of China, 2009, pp. 56-58.

[2] YAN Shu-rong and CHENG Zhi-yuan, "On Knowledge Economy and the Development Mechanism of China Personnel Resource,” Jortnal Xi'an Highway University, 2009, pp. 50-53.

[3] Xie zuoyu, Bie DunRong and Wu YingYi, "Logos Considering on Knowledge Economy and Higher Education,” Modern University Education, 2011, pp. 19-21.

[4] LI Bo, "Innovation Education Thought and the Basic Connotation," Contemporary Young Research, 2016, pp. 26-29.

[5] Hu ZhenZhen, "View Student's Innovation Ability Training from the

[6] Innovation Education Thinking of Harvard University," Henan Education, 2012, pp. 20-21.

[7] Jiao ZiGuo, "Setting Innovation Education Thinking and Training Innovation Quality Talent,” Silicon Valley, 2015, pp. 171-172.

[8] Jiang Longhua, "On Teaching Mode Reform in HEIs on the Basis of Cultivation of Innovative talents in logistics." Modern University Education, 2013, pp. 102-105. 